\title{
Preparation and characterization of monoclonal antibodies against ES antigens of Trichinella spiralis
}

\author{
J. CUI*, F. J. JING, G.Y. FU, H. J. REN, L. N. LIU, Z. Q. WANG* \\ Department of Parasitology, Medical College, Zhengzhou University, P. R. China, \\ *E-mail: wangzq@zzu.edu.cn,cuij@zzu.edu.cn
}

\begin{abstract}
Summary
Hybridomas secreting monoclonal antibodies (MAbs) against excretory-secretory (ES) antigen of Trichinella spiralis muscle larvae were produced. The 12 monoclones (designated 3A11, 7D9, 7F6, 5A7, 6H7, 39F3, 38H2, 37E7, 35B9, 29A11, 39C9 and 39A6) secreted IgM, IgG3 and $\mathrm{IgG} 2 \mathrm{~b}$, respectively. Western blot using $T$. spiralis ES antigens showed that ten of 12 MAbs recognized the bands between $119.8-19.3 \mathrm{kDa}$ (mainly $68.4-28.7 \mathrm{kDa}$ ) and two MAbs (3A11, 37E7) did not recognize any protein constituents of ES antigens. Nine of 12 MAbs also recognized the larval antigens of T. nativa, T. pseudospiralis and T. nelsoni at 40 days post-infection (dpi). No cross-reactions were found with the somatic antigens of adult worms of $P$. westermani, $C$. sinensis, and T. solium cysticercus. However, three (3A11, 6H7 and 39A6) were cross-reacted with the somatic antigens of adult worms of $S$. japonicum. Immunofluorescent location showed that the nine MAbs reacted with the cuticle and internal organs of $T$. spiralis larvae. Additionally, five and eight MAbs generated in this study can recognize the early antigens of pre-encapsulated T. spiralis larvae at $11 \mathrm{dpi}$ and $13 \mathrm{dpi}$, respectively. The generation and characterization of the MAbs against $T$. spiralis ES antigens provide foundation for the development of specific early serodiagnostic techniques for trichinellosis.
\end{abstract}

Keywords: Trichinella spiralis; MAbs; muscle larvae; excretory-secretory (ES) antigens; mice

\section{Introduction}

Trichinellosis is a serious parasitic zoonosis which is widely distributed in the world. Humans acquire the disease by ingesting raw or insufficiently cooked meat of pigs or other animals containing the Trichinella larvae. The adult worms live in the duodenal and jejunal mucosa of flesh-eating animals and humans, while the larvae live in skeletal muscles of the same hosts. Trichinella spp. infection has been documented in domestic animals (mainly pigs) and wildlife in $43(21.9 \%)$ and $66(33.3 \%)$ countries around the world, respectively. Human trichinellosis has been documented in $55(27.8 \%)$ countries around the world (Pozio, 2007). In China, 15 outbreaks of human trichinellosis, consisting of 1,387 cases and four deaths, were reported in southwestern China during 2004 - 2009 (Cui et al., 2011). So, trichinellosis is a major food-borne zoonosis with health, social, and economic impacts in China.

However, the diagnosis of trichinellosis is rather difficult because its clinical manifestations are nonspecific. The main disadvantage of serological test (such as ELISA) for the detection of anti-Trichinella antibodies is the occurrence of a high rate of false negative results during the early stage of infection, as it has shown that the maximum positive rate of $100 \%$ of ELISA in detecting anti-Trichinella antibodies was not reached until at least 1 to 3 months after human infection with the parasite (Bruschi et al., 1990; Wang et al., 1998; Gamble et al., 2004). Therefore, it is important to produce murine monoclonal antibodies (MAbs) that can be used for the development of serodiagnostic assay to detect the circulating antigens for trichinellosis.

Several MAbs have been prepared against the newborn larvae, muscle larvae or adults of T. spiralis (Arriaga et al., 1995; Boireau et al., 1997; Romarís et al., 2001; De-LaRosa et al., 2001). However, immunodiagnostic methods developed using these MAbs had problems relating to sensitivity, specificity, and reproducibility. The ES antigens of $T$. spiralis muscle larvae have been shown to the useful antigens for producing MAbs for use in the development of immunodiagnostic techniques for trichinellosis (Zhu et al., 1990; Srimanote et al., 2000; Li \& Ko 2001; Zumaquero-Ríos et al., 2012). The aim of the present study was to generate and characterize MAbs against ES antigens of $T$. spiralis muscle larvae, which would 
provide a foundation for the development of specific immunodiagnostic techniques for the specific early diagnosis of trichinellosis.

\section{Materials and methods}

\section{Parasites}

The Trichinella isolate used in the study was T. spiralis (ISS534), obtained from domestic pigs in Nanyang city of Henan Province, China. This isolate was maintained in Kunming mice at $6-8$-month intervals in our department (e.g., Department of Parasitology, Medical College, Zheng-zhou, University) and muscle larvae were recovered from infected mice by digestion of carcasses as described previously (Li et al., 2010). For comparative purposes, $T$. nativa (T2, ISS10), T. pseudospiralis (T4, ISS13) and $T$. nelsoni (T7, ISS29) obtained from the Trichinella Reference Center (IRC; Rome, Italy) were used in this study. Adult worms of tissue-dwelling helminths (Paragonimus westermani, Clonorchis sinensis and Schistosoma japonicum), and Teania solium cysticercus were stored at $-20{ }^{\circ} \mathrm{C}$ in our laboratory.

\section{Experimental animals and cell line}

Six-week-old BALB/c mice were purchased from the Experimental Animal Center of Henan province. SP2/0 mouse myeloma cells were obtained from Zhengzhou Autobio Biological Engineering Company, China. Cells were cultured in RPMI-1640 with L-glutamine, nonessential amino acids and $10 \%$ fetal bovine serum (FBS). Myeloma cells were cultured in a constant temperature incubator, which is programmed to maintain a temperature of $37^{\circ} \mathrm{C}$ and humidity of $98 \%$, in an atmosphere of $5 \% \mathrm{CO}_{2}$.

\section{Preparation of ES antigens}

The ES antigens of $T$. spiralis muscle larvae were prepared as described previously (Gamble et al., 1988; Wang et al., 2012b). In brief, after being washed thoroughly in sterile phosphate-buffered saline (pH7.4), the larvae were again washed four times in serum-free RPMI-1640 medium supplemented with $100 \mathrm{U}$ penicillin/ml and $100 \mu \mathrm{g}$ streptomycin $/ \mathrm{ml}$. The larvae were incubated in the same medium at concentration of 5000 larvae/ml for $18 \mathrm{~h}$ at $37^{\circ} \mathrm{C}$ in $5 \% \mathrm{CO}_{2}$. After incubation, larvae were removed by centrifugation $\left(6000 \times \mathrm{g}\right.$ for $25 \mathrm{~min}$ at $\left.4{ }^{\circ} \mathrm{C}\right)$, the media contained the ES products were filtered through a $0.2 \mu \mathrm{m}$ membrane into a 50-ml conical tube, then centrifuged at $4{ }^{\circ} \mathrm{C}, 15,000 \times \mathrm{g}$ for $30 \mathrm{~min}$. The supernatant contained ES was concentrated by a vacuum concentration and freezedrying (Heto Mxi-Dry-Lyo, Denmark). The protein concentration of ES antigens $(1.72 \mathrm{mg} / \mathrm{ml})$ was assayed by the method described by Bradford (1976), and then samples were aliquoted and kept at $-80{ }^{\circ} \mathrm{C}$ before use.

\section{Immunization}

Six female BALB/c mice were intraperitoneally immunized with $50 \mu \mathrm{g}$ of ES antigens and complete Freund's adjuvant, followed by three boosts with $25 \mu \mathrm{g}$ of ES antigens alone at an interval of 3 weeks. At 5 and 7 weeks after the first immunization, mice were bled and the titers of serum samples were determined, respectively. The mice were boosted once with $50 \mu \mathrm{g}$ antigens at 3 days before cell fusion.

\section{Production of hybridoma cell lines}

The mice with the highest polyclonal antibody titer were sacrificed, and aseptically splenectomized. Splenocytes were isolated, and fused with SP2/0 myeloma cells by the addition of $50 \%$ polyethylene glycol (PEG 4 000) (Roche, Basel, Switzerland)) in RPMI-1640 (Kohler \& Milstein, 1975). The fused cells were suspended in RPMI 1640 containing $1 \%$ hypoxanthine aminopterin thymidine (HAT) (Sigma) and $20 \%$ fetal calf serum (Gibco, Carlsbad, CA), and then were dispensed into 96-well cell culture plates (Corning, NY). The plates were then incubated at $37^{\circ} \mathrm{C}$ in a $\mathrm{CO}_{2}$ incubator with $5 \% \mathrm{CO}_{2}$ and $98 \%$ relative humidity for 10 to 14 days until hybridoma colonies were observed. At the end of the incubation, the supernatants of cell culture were isolated and screened by indirect enzymelinked immunosorbent assay (ELISA) as described below. Positive cultures were used in cloning, expanded, and frozen. Cloning was performed by limiting dilution technique (Kennett et al., 1980).

\section{Preparation and purification of MAbs against ES antigens of T. spiralis}

Isolated clones were intraperitoneally injected into pristine (Sigma) primed BALB/c mice and the ascitic fluid was harvested 10 days later, by the time an adequate volume accumulated. The ascites were centrifuged at $1500 \mathrm{~g}$ for $10 \mathrm{~min}$. Then, the MAbs was purified by using caprylic acid at $4{ }^{\circ} \mathrm{C}$ for $1 \mathrm{~h}$ (McKinney and Parkinson, 1987). The precipitate was centrifuged at $10000 \mathrm{~g}$ for $20 \mathrm{~min}$ at $4{ }^{\circ} \mathrm{C}$. The pellet was resuspended and dialyzed in PBS. The $\mathrm{MAb}$ isotype was determined by using the Mouse Monoclonal Antibody Isotyping Kit (Sigma, USA).

\section{ELISA assay}

MAbs from the hybridoma culture supernatants and ascites were assayed by an indirect ELISA procedure (Wang et al., 2006). Briefly, each well of polystyrene 96-well plates (Corning, NY) was coated with $100 \mu \mathrm{L}$ ES antigens of a concentration of $5 \mu \mathrm{g} / \mathrm{mL}$ in $0.05 \mathrm{M}$ bicarbonate buffer $(\mathrm{pH}$ 9.6) and incubated overnight at $4{ }^{\circ} \mathrm{C}$. After the incubation, the plates were washed three times with PBS containing $0.05 \%$ Tween-20 (PBST). After blocking with $3 \%$ skimmed milk in PBST at $37^{\circ} \mathrm{C}$ for $1 \mathrm{~h}$, the hybridoma supernatants (without dilution) or ascitic fluid (serially dilution) were added to each well $(100 \mu \mathrm{L} /$ well $)$ and incubated at $37^{\circ} \mathrm{C}$ for $1 \mathrm{~h}$. After three washings with PBST, HRP-conjugated goat anti-mouse IgG or IgM (Sigma, USA) was added and incubated at $37^{\circ} \mathrm{C}$ for $1 \mathrm{~h}$. The reactions were detected by addition of the substrate O-phenylendiamine dihydrochloride (Sigma, USA) plus $\mathrm{H}_{2} \mathrm{O}_{2}$ and stopped with $50 \mu \mathrm{L} /$ well of $2 \mathrm{M} \mathrm{H}_{2} \mathrm{SO}_{4}$. Quantification of the reactions was determined by absorbance at $490 \mathrm{~nm}$ with an ELISA reader (TECAN, Austria). 


\section{SDS-PAGE and Western blotting}

Sodium dodecyl sulphate-polyacrylamide gel electrophoresis (SDS-PAGE) was performed as previously described (Nöckler et al., 2009; Wang et al., 2011). Briefly, ES antigens of $T$. spiralis muscle larvae were diluted with loading buffer $(250 \mathrm{mM}$ Tris- $\mathrm{HCl} \mathrm{pH} 6.8,50 \%$ glycerol, $10 \%$ SDS, $5 \%$ 2-mercaptoethanol, $0.5 \%$ bromophenol blue) up to a concentration of $15 \mu \mathrm{g} / \mathrm{lane}$ and denatured at $95^{\circ} \mathrm{C}$ for $10 \mathrm{~min}$. After cooling, the proteins were separated by SDSPAGE on $12 \%$ acrylamide separating gel and $5 \%$ acrylamide stacking gels $(83 \times 73 \times 1.0 \mathrm{~mm})$ in a Mini-PROTEAN 3 Cell electrophoresis unit (Bio-Rad, USA) at $120 \mathrm{~V}$ for $2.5 \mathrm{~h}$. After electrophoresis, the gel was stained with $0.25 \%$ Coomassie brilliant blue R-250 for $4 \mathrm{~h}$, and then bleached with the eluate $(100 \mathrm{ml}$ acetic acid, $50 \mathrm{ml}$ ethanol, $850 \mathrm{ml}$ $\mathrm{dH} 2 \mathrm{O}$ ). A second gel was prepared with the same proteins.

After electrophoresis, proteins were transferred at $20 \mathrm{~V}$ for 25 min onto nitrocellulose membrane by blotting the gel in a trans-blot SD transfer cell with the electrode buffer recommended by the supplier (Bio-Rad, USA; Wang et al., 2013a). Blocking was done with $5 \%$ skimmed milks in TBST at $4{ }^{\circ} \mathrm{C}$ overnight. The strips were then probed with MAbs at $37^{\circ} \mathrm{C}$ for $1 \mathrm{~h}$. After washing, the strips were incubated at $37{ }^{\circ} \mathrm{C}$ for $1 \mathrm{~h}$ with HRP-conjugated goat antimouse IgG or IgM (Sigma, USA), and finally with 3, 3'diaminobenzidine tetrahydrochloride (Sigma, USA). The reaction was finally stopped by washing the strips with distilled water. Finally, the molecular sizes of the bands were evaluated by comparison with the molecular size ladder using a gel documentation system (GeneGenius, Syngene, USA) and related software (GeneSnap 6.08 and GeneTools, Syngene, USA).

\section{Immunolocalization}

Immunofluorscencent test (IFT) was used to the immunolocalization of MAbs in the parasite. The fresh diaphragm muscles of mice experimentally infected with $T$. spiralis at $11,13,20$ and 40 days post infection (dpi) were fixed in $10 \%$ neutral buffered formalin for $24 \mathrm{~h}$, embedded in paraffin wax, and cut into sections of $4 \mu \mathrm{m}$ thick, and then tissue sections were processed by a graded series of alcohols and rehydrated in distilled water. The immunofluorscencent staining was performed by the method described by Cui et al (1999). In brief, the tissue sections were blocked with $3 \%$ $\mathrm{H}_{2} \mathrm{O}_{2}$ diluted in PBS for $20 \mathrm{~min}$, washed three times with PBS. After blocking with $5 \%$ normal goat sera, the tissue sections containing larvae were incubated with MAbs at a dilution of 1:100 for $1 \mathrm{~h}$, then washed and incubated with a 1:200 dilution of FITC-labeled goat anti-mouse $\mathrm{IgG}$ (Biotechnology Company of Zhongshan Goldenbridge, China). The tissue sections were re-dyed with $0.3 \%$ propidium iodide (Sigma, USA) for $15 \mathrm{~min}$, and examined under fluorescent microscope (Olympus, Japan). In order to observe the recognition of larval surface by MAbs, the whole larvae at $40 \mathrm{dpi}$ were also used in IFT. The procedures of IFT with whole larvae were the same as above, but the larvae were not blocked with $\mathrm{H}_{2} \mathrm{O}_{2}$ or goat sera nor re-dyed with $0.01 \%$ Evans blue.
Specificity of the MAbs

The specificity of the MAbs was also assayed by IFT. The frozen sections with $4 \mu \mathrm{m}$ thick of adult worms of Paragonimus westermani, Clonorchis sinensis and Schistosoma japonicum, and T. solium cysticercus were prepared. The skeletal muscles of mice experimentally infected with $T$. nativa, T. pseudospiralis and T. nelsoni at $40 \mathrm{dpi}$ were also embedded in paraffin wax and cut into sections. The IFT was performed as mentioned above.

\section{Results}

Antibody titer and subtype of MAbs

ELISA assays of culture supernatants from each well showed that 12 wells (3A11, 7D9, 7F6, 5A7, 6H7, 39F3, $38 \mathrm{H} 2,37 \mathrm{E} 7,35 \mathrm{~B} 9,29 \mathrm{~A} 11,39 \mathrm{C} 9$ and 39A6) were positive to ES antigens of $T$. spiralis muscle larvae. Seven clones of MAbs belonging to IgG3, one clone of MAbs belonging to $\operatorname{IgG} 2 \mathrm{~b}$, and four clones of MAbs belonging to IgM were produced against ES antigens (Table 1). The titers of MAbs in culture supernatant and ascites determined by ELISA ranged from $1: 1280$ to $1: 6400$ and, $1: 1.28 \times 10^{5}$ to $1: 3.3 \times 10^{6}$, respectively.

\section{Western blot analysis}

SDS-PAGE analysis of $T$. spiralis muscle larval ES antigens revealed ten bands with molecular weight from 119.8 $\mathrm{kDa}$ to $14.37 \mathrm{kDa}$, of which three were the main band with molecular weight of $55.65 \mathrm{kDa}, 50.41 \mathrm{kDa}$, and $43.61 \mathrm{kDa}$ (Fig. 1). Western blotting of ES antigens showed that ten (7D9, 7F6, 5A7, 6H7, 39F3, 38H2, 35B9, 29A11, 39C9 and 39A6) of 12 MAbs recognized the bands between $119.8-19.3 \mathrm{kDa}$ (mainly 68.4 - 28.7kDa), two MAbs $(3 \mathrm{~A} 11,37 \mathrm{E} 7)$ did not recognize any protein bands of ES antigens (Fig. 2 and Table 1).

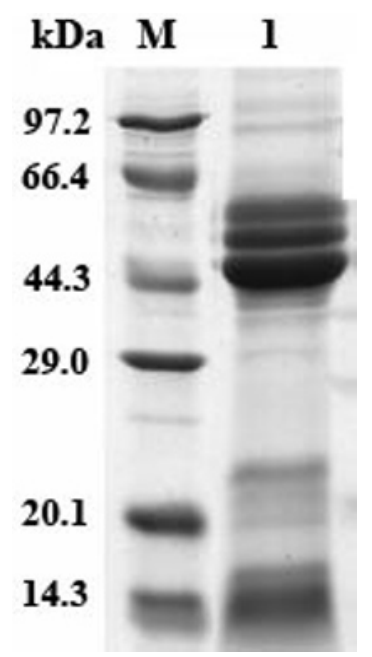

Fig. 1. SDS-PAGE of the excretory-secretory (ES) antigens of $T$. spiralis muscle larvae.

Proteins were separated in $12 \%$ polyacrylamide gels under reducing condition, the gel was stained with Coomassie brilliant blue R-250,

$M$ protein marker with low molecular weights, 1 ES antigens of $T$. spiralis muscle larvae. 


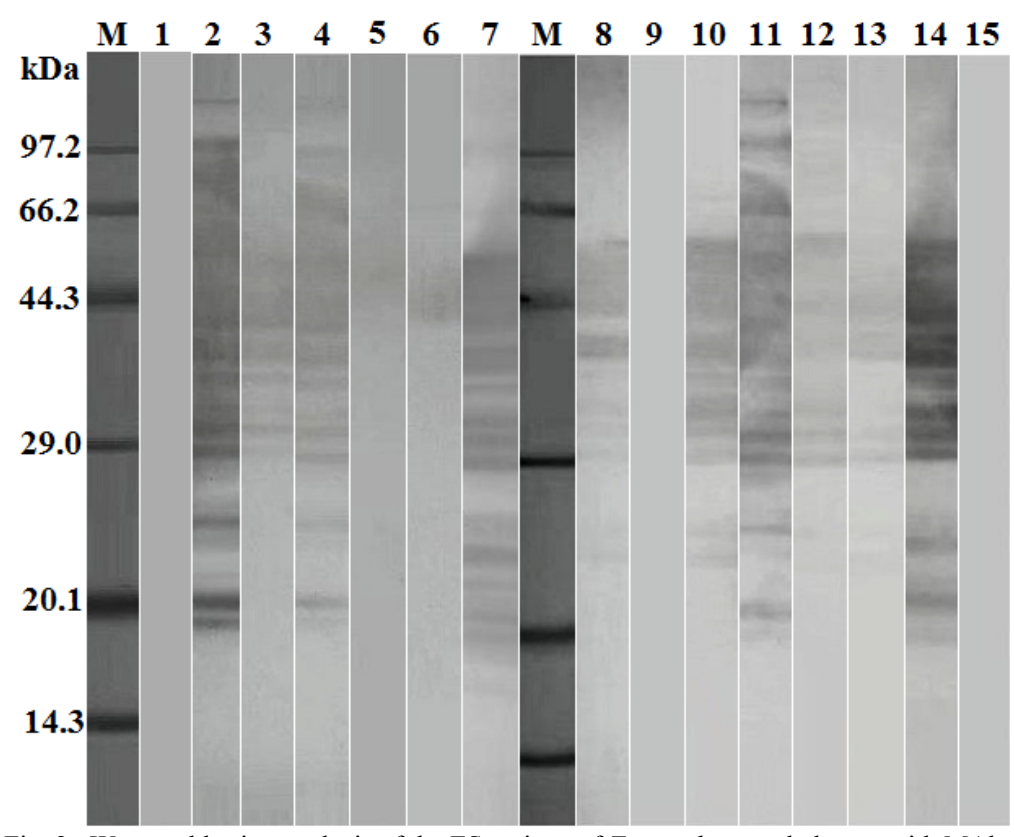

Fig. 2. Western blotting analysis of the ES antigen of $T$. spiralis muscle larvae with MAbs

Ten MAbs (Lane 2-6, 8, 10-13) recognized with the main protein bands (68.4 to $19.2 \mathrm{kDa}$ ) of ES antigens; two MAbs (Lane 1 and 9) did not recognize any protein bands of ES antigens. $M$ Protein marker with low molecular weights; 1 6 MAbs 3A11, 7D9, 7F6, 5A7, 6H7 and 39F3; 8 13 MAbs 38H2, 37E7, 35B9, 29A11, 39C9 and 39A6, 7 Sera of the infected mice; 14 Sera of mice immunized with ES antigens. 15 Sera of normal mice.

\section{Immunolocalization}

The IFT results of whole larvae at 40 dpi showed that nine MAbs (7D9, 7F6, 5A7, 39F3, 38H2, 35B9, 29A11, 39C9 and 39A6) recognized the larval cuticle and exhibited the bright green fluorescence at the external surface of the larvae (Fig. 3 and Table 1).

The results of immunofluorescent location showed that the above nine MAbs reacted with muscle sections of the infected mouse at different time intervals after infection, the immunofluorescent staining was predominantly located on the cuticles and internal organs of the larvae (Fig. 4 and Table 1). Of the nine MAbs, five MAbs (7F6, 6H7, 35B9, 29A11 and 39A6) recognize the infected muscle sections as early as $11 \mathrm{dpi}$. At 13 days, additional three MAbs (5A7, 38H2 and 39C9) also can recognize these sections. At 20 and $40 \mathrm{dpi}$, all the nine MAbs reacted with the infected muscle sections.

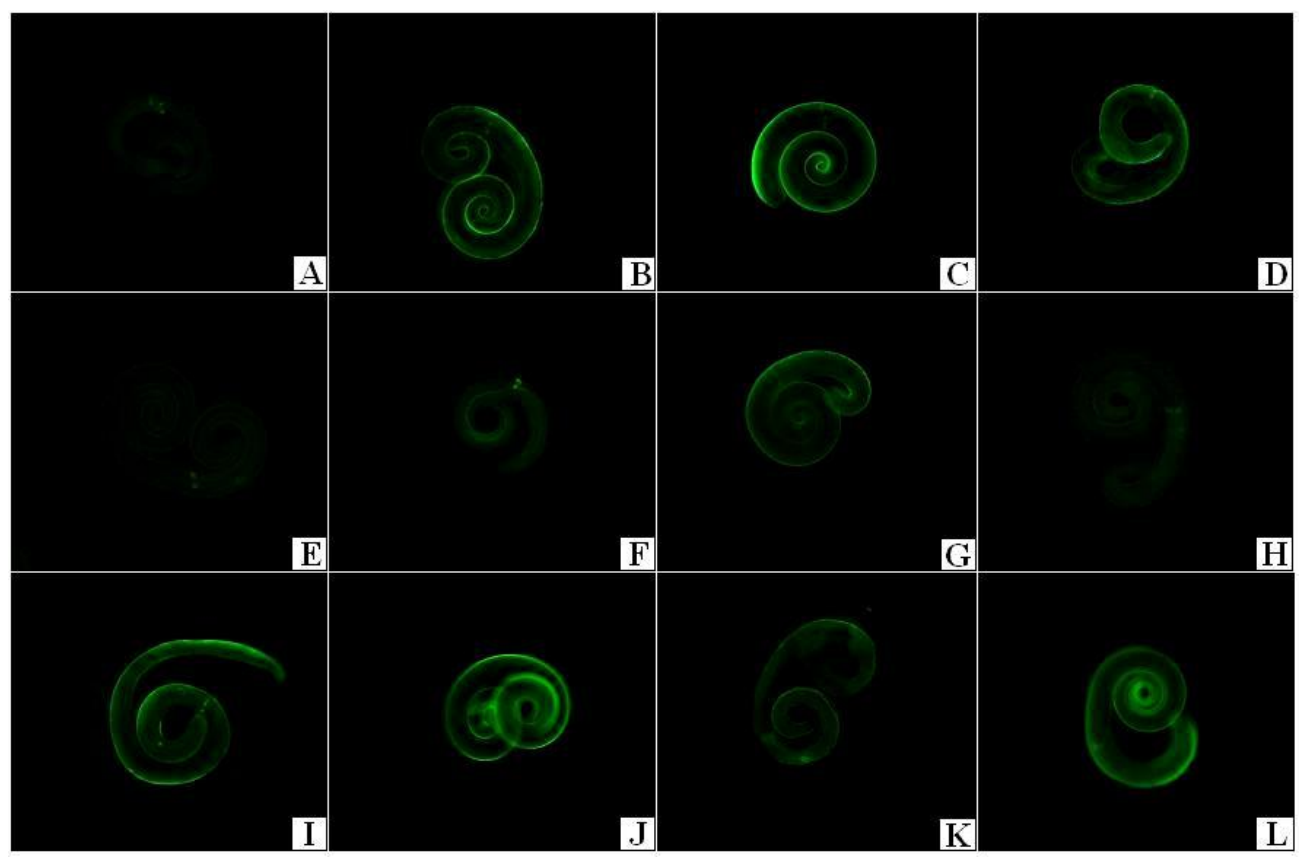

Fig. 3. Immunofluorescent staining of $T$. spiralis muscle larvae at 40 days post infection with MAbs. $A(3 \mathrm{~A} 11), E(6 \mathrm{H} 7)$ and $H(37 \mathrm{E} 7)$ showing the three MAbs that did not recognize the external surface of the larvae; $B$ (7D9), $C$ (7F6), $D(5 \mathrm{~A} 7), F(39 \mathrm{~F} 3), G(38 \mathrm{H} 2), I(35 \mathrm{~B} 9), J(29 \mathrm{~A} 11)$, $K$ (39C9) and $L$ (39A6) showing the nine MAbs that recognized the external surface of the larvae. 


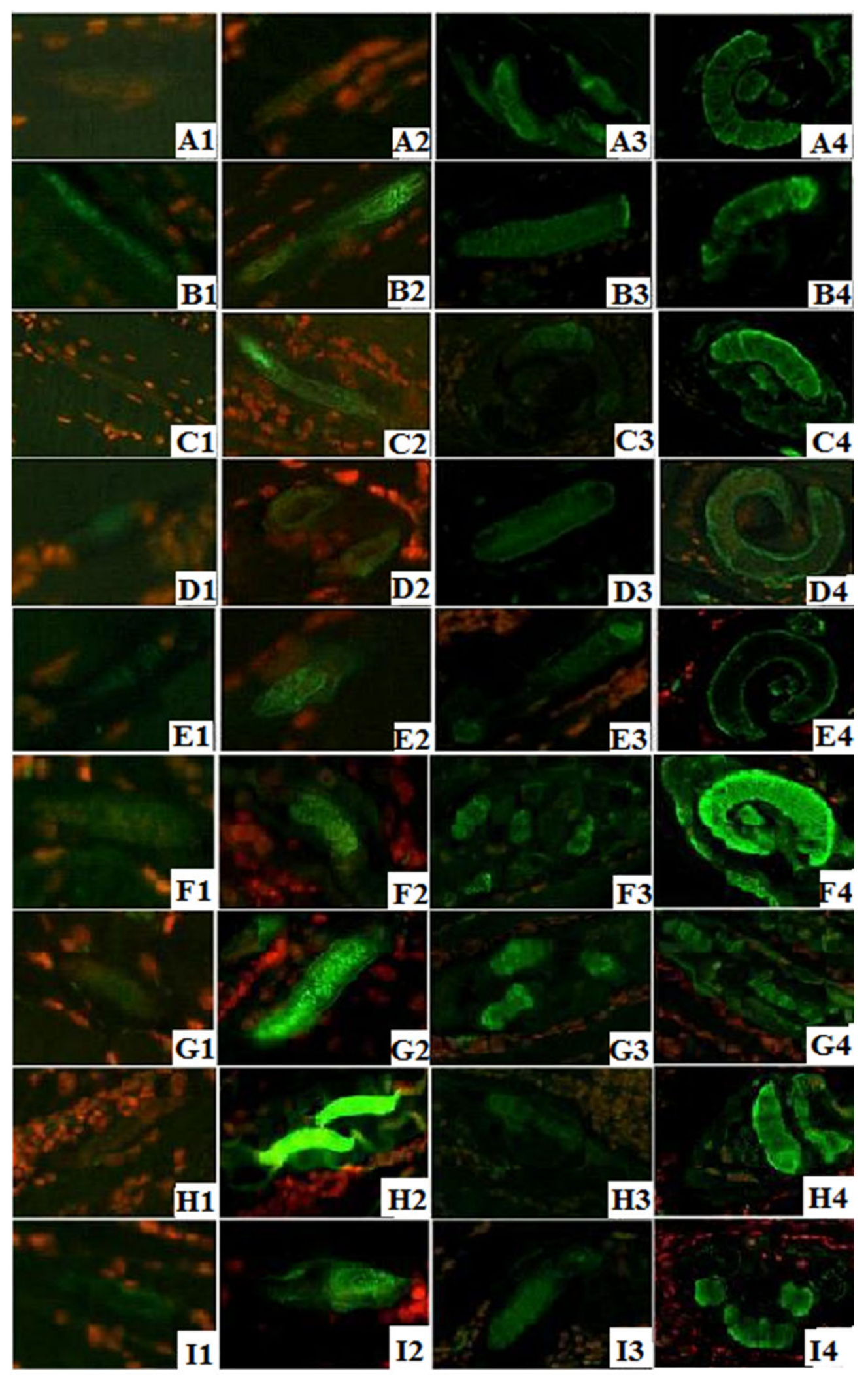

Fig. 4. Immunofluorescent staining of T. spiralis infected mouse muscle sections at different time post infection with MAbs.

The bright green fluorescence exhibited at the cuticles and internal organs of the larvae when the MAbs was positively reacted with the sections. $A$ (7D9), B (7F6), C (5A7), D (6H7), E (38H2), F (35B9), G (29A11), H (39C9), I (39A6). 1-4 represent the muscle sections of T. spiralis infected mice at $11,13,20$ and 40 days post infection, respectively. 


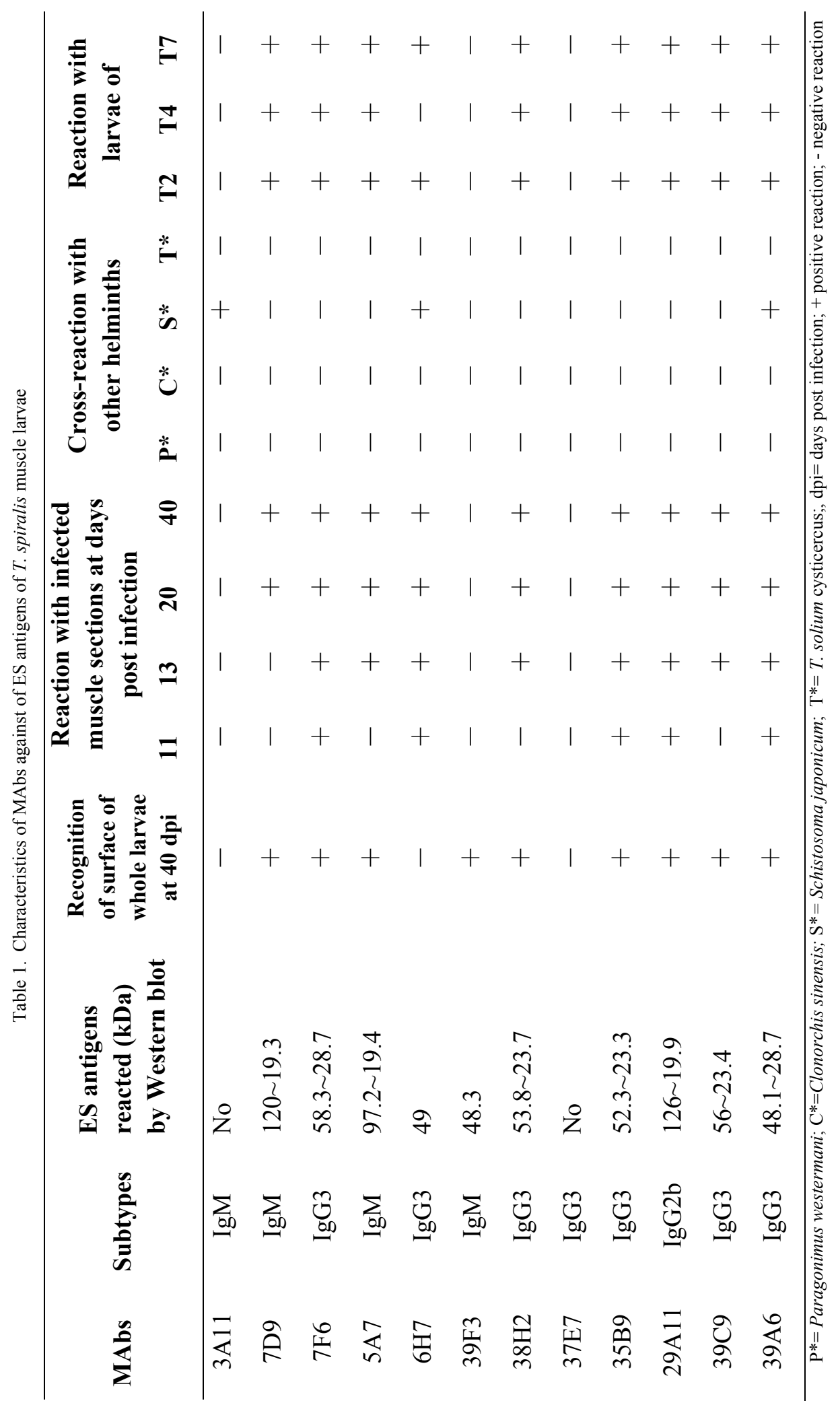


Specificity of the MAbs

The results of IFT also showed that the 12 MAbs prepared in this study were not cross-reacted with the somatic antigens of adult worms of $P$. westermani, $C$. sinensis and the sections of $T$. solium cysticercus (cysticercus cellulosae). However, three (3A11, 6H7 and 39A6) of 12 MAbs were cross-reacted with the somatic antigens of adult worms of S. japonicum.

Out of the 12 MAbs against ES antigens of $T$. spiralis muscle larvae, nine MAbs (7D9, 7F6, 5A7, 6H7, 38H2, 35B9, 29A11, 39C9 and 39A6) were cross-reacted with sections of mouse muscles infected with $T$. nativa, $T$. pseudospiralis and T. nelsoni at $40 \mathrm{dpi}$, in which the MAb $6 \mathrm{H} 7$ only recognized the encapsulated species of the genus Trichinella (T. spiralis, T. nativa and T. nelsoni) and did not recognize the non-encapsulated $T$. pseudospiralis.

\section{Discussion}

Since monoclonal antibody technique was invented by Kohler and Milstein in 1975, it has been widely used in the research on parasitic diseases (Harnett et al., 1997; Chen et al., 2010). In the production of MAbs, the choice of immunogen is the key step. The ES antigens of $T$. spiralis muscle larvae are the larval excretory and secretory products which come mainly from the stichosome, distribute throughout in various tissues of host, and are easily targeted by the immune system. So, the ES antigens are the important functional antigens of $T$. spiralis (Dea-Ayuela \& Bolas-Fernandez, 1999; Wang et al., 2013b, 2014). The ES antigen collected from muscle larvae cultivated in vitro for $24 \mathrm{~h}$ had the highly specific for the serodiagnosis of trichinellosis (Gamble et al., 1988).

In this study, the ES antigens collected from the muscle larvae maintained in vitro for $18 \mathrm{~h}$ were used to prepare the MAbs. A total of twelve MAbs against ES antigens of $T$. spiralis muscle larvae were obtained, of which 7 MAbs recognize only the antigens of Trichinella spp. and have no cross-reaction with other tissue-dwelling helminths $(P$. westermani, $C$. sinensis, $S$. japonicum, and $T$. solium cysticercus), the results indicated that these seven MAbs have the high Trichinella genus-specificity, which may be related with the common antigens among the different species of Trichinella genus (Kapel et al., 1998; Kapel \& Gamble, 2000). Acute paragonimiosis, clonorchiosis and schistosomiasis are common zoonosis in China and their main clinical manifestations are fever and eosinophilia which are similar with that of acute trichinellosis (Wang et al., 1998). When the ES antigens, their antigenic components $(40-70 \mathrm{kDa})$, and even the synthetic or recombinant antigens of $T$. spiralis were used to serodiagnosis of trichinellosis, the cross-reaction with the above helminthiasis occurred sometimes (Mahannop et al., 1995; Gamble et al., 2004; Wang et al., 2009). The generation and characterization of the seven specific MAbs against $T$. spiralis ES antigens provide foundation for the development of specific serological diagnostic techniques for trichinellosis.

The immunofluorescent location showed that the nine MAbs generated in this study reacted with the surface of the whole larvae isolated at $40 \mathrm{dpi}$ and the surface as well as internal tissues of sectioned parasites at $20 \mathrm{dpi}$ and $40 \mathrm{dpi}$, indicating their epitopes were localized at the surface and internal tissues of the larvae. The results are similar to those obtained by McLaren et al (1987). However, because the ES antigens of $T$. spiralis muscle larvae have many immunodominant epitopes, most of the MAbs against ES antigens can recognize more than one protein band (Zhu \& Bell, 1990; Romarís et al., 2001; Zumaquero-Ríos et al., 2012). Additionally, five and eight MAbs generated in this study can recognize the early antigens of the $T$. spiralis pre-encapsulated larvae in the infected muscle sections at $11 \mathrm{dpi}$ and $13 \mathrm{dpi}$, respectively. Although the reaction of five MAbs with early antigens of $T$. spiralis larvae in the sections at 11 dpi was weak, the further sandwich ELISA with mAb 35B9 and 5A7 demonstrated that the detection rate of $T$. spiralis circulating antigens in serum samples of the infected mice at 11 dpi was only $33.33 \%(5 / 15)$ and $100 \%(20 / 20)$, respectively (Wang et al., 2012a; Liu et al., 2013), suggesting that some T. spiralis antigenic epitopes present in infected muscle tissue sections at $11 \mathrm{dpi}$, which were recognized by mAb 35B9 and $5 \mathrm{~A} 7$, were also present in early circulating antigens. The results suggested that these MAbs have the potential values for early serodiagnosis of trichinellosis by sandwich ELISA assay to detect the circulating antigens in serum samples of the infected humans and animals.

\section{Acknowledgements}

This work was supported by the National Natural Science Foundation of China (No. 81271860 and No. 81371843).

\section{References}

Arriaga, C., Yepez-Mulia, L., Morilla, A., OrtegAPIERRES, G. (1995): Detection of circulating Trichinella spiralis muscle larva antigens in serum samples of experimentally and naturally infected swine. Vet. Parasitol., 58: 319 - 326. DOI: 10.1016/0304-4017(94)00775-8

Boireau, P., Vayssier, M., Fabien, J. F., Perret, C., Calamel, M., Soule, C. (1997): Characterization of eleven antigenic groups in Trichinella genus and identification of stage and species markers. Parasitology, 115: $641-651$

BRADFORD, M. M. (1976): A rapid and sensitive method for the quantitation of microgram quantities of protein utilizing the principle of protein-dye binding. Anal. Biochem., 72: 248 - 254. DOI: 10.1016/0003-2697(76)90527-3

BRUSCHI, F., TASSI, C., PozIO, E. (1990): Parasite-specific antibody response in Trichinella sp. human infection: A one year follow-up. Am. J. Trop. Med. Hyg., 43: 186 - 193 Chen, M. X., Zhang R. L, Chen, J. X., Chen, S. H., Li, X. H., GaO, S. T., GenG, Y. J., Huang, D. N., AI, L., Xu, M. J., ZHU, X. Q. (2010): Monoclonal antibodies against excretory/secretory antigens of Angiostrongylus cantonensis. Hybridoma (Larchmt), 29: 447 - 452. DOI: 10.1089/ hyb. 2010.0008 
CuI, J., WANG, Z. Q., ZHU, W., ZHANG, R. G. (1999): Seroepidemiological study of Trichinella spiralis infection in central China. Helminthologia, 36: 235 - 239

CUI, J., WAnG, Z. Q., XU, B. L. (2011): The epidemiology of human trichinellosis in China during $2004-2009$. Acta Trop., 118: 1 - 5. DOI: 10.1016/j.actatropica.2011.02.005 DeA-AuUela, M. A., Bolas-FernandeZ, F. (1999): Trichinella antigens: a review. Vet. Res., 30: $559-571$

De-La-Rosa, J. L., Moran-Tlatelpa, E., Medina, Y., Gomez-Priego, A., CorreA, D. (2001): Detection of circulating and fecal Trichinella spiralis antigens during experimental infection using monoclonal antibodies against the new born larvae. Parasite, 8: S123 - S125

Gamble, H. R., Pozio, E., Bruschi, F., Nockler, K., KAPEL, C. M., GAJADHAR, A. A. (2004): International Commission on Trichinellosis: recommendations on the use of serological tests for the detection of Trichinella infection in animals and man. Parasite, 11: 3 - 13. DOI: $10.1051 /$ parasite/20041113

Gamble, H. R., Rapic, D., Marinculic, A., Murrell, K. D. (1988): Evaluation of excretory-secretory antigens for the serodiagnosis of swine trichinellosis. Vet. Parasitol., 30: 131 - 137. DOI: 10.1016/0304-4017(88)90160-4

Harnett, W., Macdonal, M., Preece, G., Patterson, M., PARKhouse, R.M. (1997): Production of monoclonal antibodies against excretory-secretory products of adult male Onchocerca gibsoni. J. Parasitol., 83: 316 - 319. DOI: $10.2307 / 3284464$

KAPEL, C. M., GAMBLE, H. R. (2000): Infectivity, persistence, and antibody response to domestic and sylvatic Trichinella spp. in experimentally infected pigs. Int. J. Parasitol., 30: 215 - 221. DOI: 10.1016/S0020-7519 (99)00202-7

Kapel, C. M., Webster, P., Lind, P., Pozio, E., Henriksen, S. A., Murrell, K. D., NAnSen, P. (1998): Trichinella spiralis, T. britovi, and T. nativa: infectivity, larval distribution in muscle, and antibody response after experimental infection of pigs. Parasitol. Res., 84: 264 271. DOI: $10.1007 / \mathrm{s} 004360050393$

Kennett, R. H., Mckearn, T. J., Bechtol, K. B. (1980): Monoclonal antibodies: hybridomas, a new dimension in biological analyses. Plenum Press, New York, NY

KoHLER, G., Milstein, J. (1975): Continuous cultures of fused cells secreting antibody of predefined specificity. Nature, 256: 495 - 497. DOI: 10.1038/256495a0

LI, F., CuI, J., WANG, Z. Q., JIANG, P. (2010): Sensitivity and Optimization of Artificial Digestion in the Inspection of Meat for Trichinella spiralis. Foodborne Pathog. Dis., 7: 879 - 885. DOI: 10.1089/fpd.2009.0445

LI, C. K., Ko, R. C. (2001): The detection and occurrence of circulating antigens of Trichinella spiralis during worm development. Parasitol. Res., 87: 155 - 162. DOI: 10.1007/PL00008569

LiU, L. N., Jing, F. J., CuI, J., Fu, G. Y., WANG, Z. Q. (2013): Detection of circulating antigen in serum of mice infected with Trichinella spiralis by an $\operatorname{IgY}-\operatorname{IgM} \mathrm{mAb}$ sandwich ELISA. Exp. Parasitol., 133: 150 - 155. DOI: 10.1016/j.exppara.2012.11.001
Mahannop, P., Chaicumpa, W., Setasuban, P., MoraKOTE, N., TAPCHAISRI, P. (1992): Immunodiagnosis of human trichinellosis using excretory-secretory (ES) antigen. J. Helminthol., 66: 297 - 304. DOI: 10.1017/S002 2149X00014759

MCKInNEY, M. M., PARKInson, A. (1987): A simple, nonchromatographic procedure to purify immunoglobulins from serum and ascites fluid. J. Immunol. Methods, 96: 271 - 278. DOI: 10.1016/0022-1759(87)90324-3

McLaren, D. J., Ortega-Pierres, G., Parkhouse, R. M. (1987): Trichinella spiralis: immunocytochemical localization of surface and intracellular antigens using monoclonal antibody probes. Parasitology, 94: $101-114$. DOI: $10.1017 / \mathrm{S} 003118200005349 \mathrm{X}$

Nöckler, K., Reckinger, S., Broglia, A., MayerSCHOLL, A., BAHN, P. (2009): Evaluation of a Western blot and ELISA for the detection of anti-Trichinella-IgG in pig sera. Vet. Parasitol., 163: 341 - 347. DOI: 10.1016/j.vetpar.2009.04.034

PozIO, E. (2007): World distribution of Trichinella spp. infections in animals and humans. Vet. Parasitol., 149: 3 21. DOI: 10.1016/j.vetpar.2007.07.002

Romaris, F., Escalante, M., Valins, B., Seoane, R., WANG, Z. Q., LEIRO, J., UBEIRA, F. M. (2001): Characterization of two monoclonal antibodies raised in Btk(xid) mice that recognize phosphorylcholine-bearing antigens from Trichinella and other helminths. Parasite Immunol., 23: 313 - 322. DOI: 10.1046/j.1365-3024.2001.00388.x

Srimanote, P., ItTiPrasert, W., Sermsart, B., Chaisri, U., Mahannop, P., Sakolvaree, Y., Tapchaisri, P., MaleEWONG, W., Kurazono, H., Hayashi, H., CHAICUMPA, W. (2000): Trichinella spiralis- specific monoclonal antibodies and affinity-purified antigen-based diagnosis. Asian Pac. J. Allergy Immunol., 18: 37 - 45

WANG, L., WANG, Z. Q., CUI, J. (2013a): Proteomic analysis of the changed proteins of Trichinella spiralis infective larvae after co-culture in vitro with intestinal epithelial cells. Vet. Parasitol. 194: 160 - 163. DOI: 10.1016/j.vetpar.2013.01.045

WANG, L., WANG, Z. Q., Hu, D. D., CuI, J. (2013b): Proteomic analysis of Trichinella spiralis muscle larval excretory-secretory proteins recognized by early infection sera. Biomed. Res. Int., 2013: 139745. DOI: 10.1155/2013/ 139745

WAng, L., CuI, J., Hu, D. D., LiU, R. D., WAnG, Z. Q. (2014): Identification of early diagnostic antigens from major excretory-secretory proteins of Trichinella spiralis muscle larvae using immunoproteomics. Parasit. Vectors, 7: 40. DOI: 10.1186/1756- 3305-7-40

WANG, R., WANG, Z. Q., CUI, J. (2009): Immunodiagnostic value and immune protection of the recombinant Ts21 antigen of Trichinella spiralis. Chin. J. Parasitol. Parasit. Dis., 27: 17 - 21 (In Chinese)

WANG, S. W., WANG, Z. Q., CUI, J. (2011): Protein change of intestinal epithelial cells induced in vitro by Trichinella spiralis infective larvae. Parasitol. Res., 108: 593 - 599. DOI: $10.1007 / \mathrm{s} 00436-010-2102-9$ 
WanG, Z. Q., CuI, J., WeI, H. Y., HAN, H. M., ZhanG, H. W., LI, Y. L. (2006): Vaccination of mice with DNA vaccine induces the immune response and partial protection against T. spiralis infection. Vaccine, 24: 1205 - 1212. DOI: 10.1016/j.vaccine.2005.08.104

WANG, Z. Q., CUI, J., WU, F., MAO, F. R., JIN, X. X. (1998): Epidemiological, clinical and serological studies on trichinellosis in Henan Province, China. Acta Trop., 71: 255 268. DOI: $10.1016 / \mathrm{S} 0001-706 \mathrm{X}(98) 00072-2$

WANG, Z. Q., FU, G. Y., JING F. J., JIN, J., REN, H. J., JIANG, P., CUI, J. (2012a): Detection of Trichinella spiralis circulating antigens in serum of experimentally infected mice by an IgY-mAb sandwich ELISA. Foodborne Pathog. Dis., 9: 727 - 933. DOI: 10.1089/fpd.2012. 1157

WANG, Z. Q., WANG, L., CUI, J. (2012b): Proteomic analysis of Trichinella spiralis proteins in intestinal epithelial cells after culture with their larvae by shotgun LC-MS/MS approach. J. Proteomics, 75: 2375 - 2383. DOI: 10.1016/j.vetpar.2013.01.045

ZHU, D. Z., BELL, R. G. (1990): Trichinella spiralis: murine strain variation in response to monoclonally defined, protective, nonstage-specific antigens. Exp. Parasitol., 70: 330 - 343. DOI: 10.1016/0014-4894(90)90115-S 